\title{
Targeted Therapies in Melanoma: Knowledge, Resistance and Perspectives
}

\author{
Maria Colombino $^{1^{*}}$, Maria Cristina Sini ${ }^{1}$, Amelia Lissia $^{2}$, Antonio Cossu ${ }^{2}$, and Giuseppe Palmieri ${ }^{1}$ \\ ${ }^{1}$ Unit of Cancer Genetics, Institute of Biomolecular Chemistry (ICB), National Research Council (CNR), Italy \\ ${ }^{2}$ University Hospital Health Unit - Azienda Ospedaliero Universitaria (AOU), Via Matteotti, 07100 Sassari, Italy
}

*Corresponding author: Dr. Maria Colombino, Unit of Cancer Genetics, Institute of Biomolecular Chemistry (ICB), National Research Council (CNR), Traversa La Crucca, 3 - Baldinca Li Punti, 07100 Sassari, Italy, Tel. +39 079 2841239; Fax +39 079 2841299; E-mail: colombinom@yahoo.it

Received date: Mar 18, 2014, Accepted date: May 25, 2014, Published date: May 31, 2014

Copyright: (c) 2014 Colombino M, et al. This is an open-access article distributed under the terms of the Creative Commons Attribution License, which permits unrestricted use, distribution, and reproduction in any medium, provided the original author and source are credited.

\begin{abstract}
Several molecular mechanisms appear to play a major role in melanoma genesis and progression. Current targeted therapies focus on contrasting the activation of RAS/RAF/MEK/ERK and, to a less extent, PI3K/AKT pathways. Development of inhibitors of key effectors (mainly, BRAF mutant and MEK) has significantly improved treatment of patients with advanced melanoma. However, only rarely tumours present a durable regression due to a large variety of acquired and intrinsic mechanisms that drive resistance to the main targeted inhibitors. All these evidence suggest that in melanoma, as probably in all types of cancer, use of a combinatorial treatment approach, instead of targeting a single component of melanomagenesis pathways, could delay or prevent the emergence of resistance mechanisms responsible of tumour relapse. In this sense, a crucial step is thus represented by the full knowledge of such molecular mechanisms
\end{abstract}

Keywords: Melanoma; MAPK pathway; Targeted therapy; Drug resistance

\section{Introduction}

Molecular mechanisms underlying pathogenesis of melanoma are complex. Single genetic or epigenetic alterations are not crucial person; rather, the interaction of some or most of such modifications may participate into the development and progression of the disease as well as contribute in generating distinct biological subsets of melanomas with different clinicopathological behaviors. Specific alterations have been described as deeply involved in melanomagenesis: induction of cell proliferation and/or impairment of the mechanisms controlling the melanocyte senescence (both promoting primary clonal selection and expansion), and suppression of the apoptosis (sustaining the cancer cell survival and tumor progression).

According to such a complex scenario, targeting a single component of the multiple pathways involved in pathogenesis is unlikely to yield a durable anti-tumor response in melanoma patients. Indeed, activation of alternative pathogenetic effectors is at basis of the development of resistance to target inhibitors.

Among others, the cascade of Ras, Raf, Mek and Erk proteins which constitutes the mitogen-activated protein kinase (MAPK) pathway-has been reported to play a crucial role in melanoma pathogenesis [1]. Indeed, the ERK1/2 proteins have been found to be constitutively activated in melanoma, mostly as a consequence of mutations in upstream components of the pathway and their increased activity has been implicated in rapid cell growth as well as enhanced cell survival and resistance to apoptosis [1]. On this regard, activating mutations in BRAF and NRAS genes were found in approximately $45 \%$ and $15 \%$ of all melanomas, respectively (somatic mutations in such genes are mutually exclusive [2,3].
Treatment of patients with advanced melanoma has actually several effective options. Targeted therapy with BRAF inhibitors (vemurafenib, dabrafenib) or MEK inhibitors (trametinib) as well as immunomudulatory compounds [the anti-CTLA4 agent (ipilimumab) and the anti-PD-1 or anti-PD-L1 agents (nivolumab, lambrolizumab,MPDL3280A)] are all associated with improved clinical benefits, thus allowing to overcome the ineffectiveness of the conventional therapies [4].

Vemurafenib and dabrafenib have shown to benefit patients with BRAF activating mutation through achievement of a rapid tumour shrinkage in the majority of cases [5]. Treatments with both these drugs improve response rates and progression-free survival (PFS), with a favourable impact on overall survival (OS) [5]. MEK inhibitors alone or combined with a BRAF inhibitors have been recently demonstrated to exert a similar clinical efficacy [6].

Vast majority (up to 80\%) of melanoma patients carrying BRAF mutations shows clinical and pathological response to therapy-with different rates of tumour reduction-when treated with either a BRAF inhibitor or a MEK inhibitor [7,8]. However, most of them develop resistance within 6-8 months after treatment initiation, as consequence of reactivation of the MAPK pathway or activation of alternative signalling pathways [9-13]. Nevertheless, a fraction of cases are primarily refractory due to an intrinsic resistance to such inhibitors [13].

The development of tumor resistance to single targeted agents appears inevitable and, given the high clinical responses, it is of pivotal importance to identify alternative therapies that overcome this problem [9-13].

\section{Targeted Therapies and MAPK Pathway Components}

Although majority of molecular mechanisms involved into the development, progression, and resistance-to-therapy of melanoma remains still largely unknown, several genes and cell-signalling 
pathways have been implicated [14]. Canonical activation of MAPK pathway occurs when stimulation of the growth factor receptor leads to the activation of RAS family member (H-, N- or KRAS). Activated RAS interact with RAF isoform (A-, B- or CRAF) with consequent activations of RAF notably, RAF activation appears only after the formation of homo-or heterodimers between different isoform, that lead to the phosphorylation of MEK which activates ERK through a phosphorylation event [14-19].

Despite RAS has been largely implicated in tumour initiation and promotion, RAS itself has not become a successful target of therapy $[20,21]$. The strategies used to develop drugs able to inhibit the RAS activity are aimed at preventing its interaction with several components of the upstream or downstream signalling pathways regulated by this protein [21]. In this sense, a promising way of interfering with Ras function seemed to be the inhibition of farnesyltransferase, the enzyme coupling a 15-carbon isoprenyl group to Ras proteins, by farnesyltransferase inhibitors. The block of farnesylation markedly impairs the functioning of active RAS protein [22]. While a good in vitro antitumour activity has been reported in human melanoma cell lines, with downregulation of ERK and/or AKT and induction of apoptosis [22,23], farnesyltransferase inhibitors have always failed to be effective in melanoma patients (even if all cohorts treated with these agents were never selected for the activated-RAS status $[24,25])$. Lonafarnib, a recently discovered farnesyltransferase inhibitor, did not significantly inhibit growth of metastatic melanoma cells nor sensitize melanoma cells to the chemotherapeutic agents tested. In contrast, lonafarnib significantly augmented the growth inhibitory effects of the pan-RAF inhibitor sorafenib, inducing marked apoptosis and abrogated invasive melanoma growth [26]. Therefore, combination of farnesyltransferase inhibitors with other pathwaytargeted drugs or, alternatively, a more stringent selection of the patients' cohorts could be helpful to increase the clinical efficacy of such compounds.

Therapeutic strategies have thus been focused on inhibiting downstream effectors of the RAS-driven pathways, MAPK and PI3KAKT. Table 1 summarizes the main targeted agents introduced in clinical practice, as registered into the ClinicalTrial.gov database of the U.S. National Institutes of Health (at the https://clinicaltrials.gov/).

\begin{tabular}{|c|c|c|}
\hline Target & Clinical agents & Activity \\
\hline BRAF & $\begin{array}{l}\text { Vemurafenib } \quad \text { Dabrafenib LGX818 } \\
\text { R05212054 }\end{array}$ & $\begin{array}{l}\text { Selectively binds to and inhibits activated BRAF, inhibiting the proliferation of tumor cells with } \\
\text { mutated BRAF gene }\end{array}$ \\
\hline \multirow{3}{*}{ MEK } & $\begin{array}{l}\text { Trametinib Selumetinib } \\
\text { Pimasertib TAK-733MSC2015103B }\end{array}$ & $\begin{array}{l}\text { Binds to and inhibits MEK } 1 \text { and MEK } 2 \text {, resulting in inhibition of growth factor-mediated cell } \\
\text { signaling and tumor cell proliferation }\end{array}$ \\
\hline & Cobimetinib & $\begin{array}{l}\text { Binds to and inhibits the catalytic activity of MEK1, resulting in inhibition of activating ERK2 } \\
\text { phosphorylation and tumor cell proliferation }\end{array}$ \\
\hline & RO4987655 & $\begin{array}{l}\text { Binds to and inhibits MEK 1, which may result in inhibition of MEK-dependent cell signaling and } \\
\text { tumor cell proliferation }\end{array}$ \\
\hline Dual MEK-RAF & RO5126766 & $\begin{array}{l}\text { Specifically inhibits kinase activities of Raf and MEK, resulting in inhibition of target gene } \\
\text { transcription that promotes malignant cell transformation }\end{array}$ \\
\hline \multirow{2}{*}{ Pan-RAF } & Sorafenib & $\begin{array}{l}\text { Blocks RAF kinase (regardless of mutation status) and other kinases that control cell division } \\
\text { and proliferation }\end{array}$ \\
\hline & RAF265 & $\begin{array}{l}\text { Binds and inhibits Raf kinases and VEGFR-2, which may result in reduction of tumor cell } \\
\text { growth and proliferation }\end{array}$ \\
\hline PI3K & $\begin{array}{llll}\text { BKM120 } & \text { XL147 } & \text { ZSTK474 } & \text { PX-866 } \\
\text { GDC-0941 } & & \end{array}$ & $\begin{array}{l}\text { Reversibly binds to class } 1 \mathrm{PI} 3 \mathrm{~K} \text { s in an ATP-competitive manner, inhibiting the production of } \\
\text { PIP3 and activation of the PI3K signaling pathway; this may result in inhibition of tumor cell } \\
\text { growth and survival in susceptible tumor cell populations }\end{array}$ \\
\hline AKT & MK2206 GSK2110183 GDC-0068 & $\begin{array}{l}\text { Binds to and inhibits AKT in a non-ATP-competitive manner, resulting in inhibition of the } \\
\text { PI3K/AKT signaling pathway and tumor cell proliferation and induction of tumor cell apoptosis }\end{array}$ \\
\hline \multirow{3}{*}{ mTOR } & AZD8055 TemsirolimusRidaforolimus & $\begin{array}{l}\text { Binds to and inhibits mTOR, resulting in decreased expression of mRNAs necessary for cell } \\
\text { cycle progression and arresting cells in the G1 phase of the cell cycle }\end{array}$ \\
\hline & Sirolimus & $\begin{array}{l}\text { Binds to FKBP-12 to generate an immunosuppressive complex that binds to and inhibits } \\
\text { mTOR, resulting in inhibition of } \mathrm{T} \text { lymphocyte activation and proliferation that occurs in } \\
\text { response to antigenic and cytokine (IL-2, IL-4, and IL-15) stimulation and inhibition of antibody } \\
\text { production }\end{array}$ \\
\hline & Everolimus OSI-027 & $\begin{array}{l}\text { Binds to and inhibits both the raptor-mTOR complex } 1 \text { (TORC1) and the rictor-mTOR complex } \\
2 \text { (TORC2), resulting in tumor cell apoptosis and inhibition of tumor cell proliferation }\end{array}$ \\
\hline \multirow[b]{2}{*}{ Dual PI3K/mTOR } & XL765/SAR245409 BEZ235 GDC-0980 & $\begin{array}{l}\text { Inhibits both PI3K kinase and mTOR kinase, which may result in tumor cell apoptosis and } \\
\text { growth inhibition in susceptible tumor cell populations. }\end{array}$ \\
\hline & GSK2126458 & $\begin{array}{l}\text { Binds to and inhibits } \mathrm{PI} 3 \mathrm{~K} \text { in the } \mathrm{PI} 3 \mathrm{~K} / \mathrm{mTOR} \text { signaling pathway, which may trigger the } \\
\text { translocation of cytosolic Bax to the mitochondrial outer membrane, increasing mitochondrial } \\
\text { membrane permeability and inducing apoptotic cell death }\end{array}$ \\
\hline
\end{tabular}




\begin{tabular}{|c|c|c|}
\hline & SF1126 & $\begin{array}{l}\text { Selectively binds to cell surface integrins and, upon cell entry, the agent is hydrolyzed to the } \\
\text { active drug SF1101; Inhibits all isoforms PI3K, mTOR and DNA-PK, wich may inhibit tumor cell } \\
\text { and tumor endothelial cell proliferation and survival }\end{array}$ \\
\hline CDK4/6 & LEE011 LY2835219 Palbociclib & $\begin{array}{l}\text { Specifically inhibits CDK4 and } 6 \text {, thereby inhibiting Rb protein phosphorylation, that prevents } \\
\text { CDK-mediated G1-S phase transition, thereby arresting the cell cycle in the G1 phase, } \\
\text { suppressing DNA synthesis and inhibiting cancer cell growth }\end{array}$ \\
\hline $\mathrm{Src}$ & Dasatinib & Binds to and inhibits the growth-promoting activities of SRC-family protein-tyrosine kinases \\
\hline Met & Tivantinib & $\begin{array}{l}\text { Binds to the c-Met protein and disrupts c-Met signal transduction pathways, which may induce } \\
\text { cell death in tumor cells overexpressing c-Met protein or expressing consitutively activated c- } \\
\text { Met protein }\end{array}$ \\
\hline IGF1R & Ganitumab & $\begin{array}{l}\text { Binds to membrane-bound IGF-1R, preventing binding of the ligand IGF-1 and the subsequent } \\
\text { triggering of the PI3K/Akt signaling pathway; inhibition of this survival signaling pathway may } \\
\text { result in the inhibition of tumor cell proliferation and the induction of tumor cell apoptosis }\end{array}$ \\
\hline HSP90 & XL888 & $\begin{array}{l}\text { Specifically binds to Hsp90, inhibiting its chaperone function and promoting the proteasomal } \\
\text { degradation of oncogenic signaling proteins involved in tumor cell proliferation and survival; } \\
\text { inhibition of tumor cell proliferation may result }\end{array}$ \\
\hline CTLA-4 & Ipilimumab & enhances T-cell activation and blocks B7-1 and B7-2 T-cell co-stimulatory pathways \\
\hline PD-1 & Nivolumab & $\begin{array}{l}\text { Binds to and blocks the activation of } \mathrm{PD}-1 \text {, an Ig superfamily transmembrane protein, by its } \\
\text { ligands PD- } \mathrm{L} 1 \text { and } \mathrm{PD}-\mathrm{L} 2 \text {, resulting in the activation of } \mathrm{T} \text {-cells and cell-mediated immune } \\
\text { responses against tumor cells or pathogens }\end{array}$ \\
\hline PD-L1 & MDX-1105 Pembrolizumab MPDL3280A & $\begin{array}{l}\text { Binds to PD-1, an inhibitory signaling receptor expressed on the surface of activated T cells, } \\
\text { and blocks the binding to and activation of PD- } 1 \text { by its ligands, which results in the activation of } \\
\text { T-cell-mediated immune responses against tumor cells }\end{array}$ \\
\hline Interleukin-2 & Aldesleukin & $\begin{array}{l}\text { Binds to and activates IL-2 receptor; activation of tyrosine kinase Jak } 3 \text {; and phosphorylation of } \\
\text { tyrosine residues on IL-2R beta chain, resulting in an activated receptor complex. may induce } \\
\text { T cell-mediated tumor regression in some tumor types }\end{array}$ \\
\hline
\end{tabular}

Table 1: Principal targeted therapies in completed or on-going clinical trials

\section{Targeting BRAF}

BRAF is the second kinase in the cascade of MAPK pathway: the identification that a high percentage of melanomas is driven by oncogenic BRAF has led to explore the most effective ways of inhibiting the constitutively active MAPK pathway. From these studies, BRAF inhibitors have been confirmed to represent the most promising agents for treating BRAF-mutant melanomas.

The first drug developed against BRAF was the BAY 43-9006 or sorafenib, which is however unspecific for mutated BRAF and suppresses activity of several different kinases (indeed, it is recognized as a multikinase inhibitor) [27]. This lack of target specificity produced a negative consequence on the outcome of the treatment of melanoma: in fact sorafenib was proven to be clinically ineffective as either single agent or in combination with chemotherapeutic drugs (i.e. carboplatin and paclitaxel) [28-30].

Vemurafenib (PLX4032), a second generation anti-BRAF compound that acts as potent and selective inhibitor of mutated BRAF kinase, has been demonstrated to be highly effective in melanoma patients carrying the V600EBRAF mutation [31]. Based on outstanding results shown from phase I and II studies, a randomised phase III study of vemurafenib compared to dacarbazine as standard treatment was launched and rapidly completed [32]. As hypothesized, patients treated with vemurafenib presented an overall survival at 6 months of $84 \%$ (95\% CI: 78-89) as compared to patients treated with dacarbazine showing an overall survival of $64 \%$ (95\% CI: 56-73) [32]. Additionally, patients from vemurafenib group presented a relative reduction of $63 \%$ in the risk of death and of $74 \%$ in the risk of either death or disease progression, as compared with those undergoing dacarbazine treatment [32]. Reproducing the same good clinical activity of vemurafenib, dabrafenib (previously known as GSK2118436) has been recognized as an additional potent and specific BRAF mutant inhibitor: it significantly improved progression-free survival as compared with dacarbazina [33]. Interestingly, dabrafenib seems to be equally active on different mutations at codons 600 of the BRAF gene (V600E/K/D/R) [33-35]. Overall, a clinical benefit has been reported up to an unprecedented $80 \%$ rate of BRAF-mutated patients treated with vemurafenib or dabrafenib; response to each of these oral agents occurs within few days or weeks [36].

In addition to the inhibitory activity in BRAF-mutant cells, which is revealed by the decreased level of phosphorylated ERK1/2 proteins and consequent growth arrest, vemurafenib and dabrafenib also can activate MAPK pathway in tumour cells with a wild-type BRAF through RAF-mediated induction of ERK1/2 phosphorylation [37,38]. It has been shown that wild-type RAF kinase activation induces RAF dimerization with paradoxical increase in MAPK signalling as result of increased dimer formation (CRAF-CRAF or BRAF-CRAF) that in turn activates MEK and, subsequently, ERK. This process is enhanced by the presence of an oncogenic RAS mutation [38-41]. The paradoxical activation of ERK might explain the formation of keratoacanthomas and squamous cell carcinomas among patients treated with BRAF inhibitors as well as the development of an acquired resistance to these drugs [38,41]. In fact, even though the response rates are high, the duration of response has been limited due to development of resistance: the median duration of response was 6 to 8 months. 
Page 4 of 12

\section{Targeting MEK}

Since reactivation of the downstream MEK-ERK pathway seems to represent the main mechanism of resistance to BRAF inhibitors, a promising strategy for overcoming such a limited persistence of the antiproliferative effects was to introduce new compounds blocking MEK1/2 proteins into the treatment options; indeed, several MEK inhibitors have been tested in clinical trials. While BRAF inhibitors only inhibit ERK signalling in cells with mutant BRAF, MEK inhibitors block ERK pathway in both tumour and normal cells. As single agents, these compounds (AS703026, AZD6244, E6201, GSK1120212, GDC0973, MEK162) have shown a markedly high activity in patients carrying tumours with constitutive activation of the RAS/BRAF/MEK/ERK signalling cascade. Detection of RAS mutations in primary tumours seems to represent the strongest marker for selecting patients with the highest chance to respond to MEK inhibitors; AS703026 and AZD6244 have activity in KRAS mutant colon cancer cell lines/xenografts in combination with cetuximab $[42,43]$, whereas GSK1120212 (also known as trametinib) has been found to be effective in NRAS-mutated melanoma [44]. In melanoma patients carrying BRAF mutations, the response to MEK inhibitors seems to be partially dependent on exposition to prior therapy with BRAF inhibitors; for GSK1120212, a significant clinical activity was observed in BRAF-inhibitor-naïve patients only [44,45]. Similarly, the response seems to hinge on status of the PI3K-AKT pathway: for selumetinib (AZD6244) and E6021 a significantly low responsiveness to MEK inhibitors was found in BRAF mutant melanomas expressing high levels of phosphorylated AKT [46] or presenting PTEN inactivation with subsequent stimulation of downstream PI3K signalling [47], respectively. In other words, coexistence of an unaffected PI3K-AKT status may contribute to increase sensitivity to MEK inhibitors in melanomas whose MAPK pathway is activated

\begin{tabular}{|c|c|c|c|c|c|c|c|}
\hline Reference & Trial & $\begin{array}{l}\text { No. of } \\
\text { pts }\end{array}$ & Target & $\begin{array}{l}\text { Molecular } \\
\text { alteration }\end{array}$ & Agent(s) & Clinical Benefits & Adverse events \\
\hline $\begin{array}{l}\text { Chapman } \\
2011\end{array}$ & Phase III & 675 & BRAF & $\mathrm{BRAF}^{\mathrm{V} 600 \mathrm{E}}$ mut & Vemurafenib & $\begin{array}{l}\text { ORR: about } 50 \% \text {; PFS: } 5.3 \\
\text { months; OS: } 84 \% \text { at } 6 \\
\text { months }\end{array}$ & $\begin{array}{l}\text { arthralgia, fatigue, cutaneous events, squamous } \\
\text { cell carcinoma (SCC), keratoacanthoma (KA), or } \\
\text { both }\end{array}$ \\
\hline $\begin{array}{l}\text { Hauschild } \\
2012\end{array}$ & Phase III & 250 & BRAF & $\mathrm{BRAF}^{\mathrm{V} 600} \mathrm{mut}$ & Dabrafenib & $\begin{array}{l}\text { ORR: about } 60 \% \text {; PFS: } 5.1 \\
\text { months; OS: } 42 \% \text { at } 5 \\
\text { months }\end{array}$ & $\begin{array}{l}\text { arthralgia, pyrexia, fatigue, headache, } \\
\text { hyperkeratosis, papillomas, palmar-plantar } \\
\text { erythrodysesthesia, SCC, KA, basal cell } \\
\text { carcinoma, mycosis fungoides }\end{array}$ \\
\hline Robert 2012 & Phase III & 322 & MEK & $\mathrm{BRAF}^{\mathrm{V} 600}$ mut & Trametinib & $\begin{array}{l}\text { ORR: about } 22 \% \text {, PFS: } 4.8 \\
\text { months; OS: } 81 \% \text { at } 6 \\
\text { months }\end{array}$ & $\begin{array}{l}\text { rash, diarrhea, nausea, vomiting, fatigue, } \\
\text { peripheral edema, alopecia, hypertension, } \\
\text { constipation, central serous retinopathy and } \\
\text { retinal-vein occlusion }\end{array}$ \\
\hline $\begin{array}{l}\text { Flaherty } \\
2012\end{array}$ & $\begin{array}{l}\text { Phase } \\
\text { I/II }\end{array}$ & $247 / 162$ & $\begin{array}{l}\text { BRAF+ } \\
\text { MEK }\end{array}$ & $\begin{array}{l}\mathrm{BRAF}^{\mathrm{V} 600 \mathrm{E} / \mathrm{K}} \\
\text { mut }\end{array}$ & $\begin{array}{l}\text { Dabrafenib+ } \\
\text { Trametinib }\end{array}$ & $\begin{array}{l}\text { ORR: about } 76 \% \text {, PFS: } 9.4 \\
\text { months; OS: } 41 \% \text { at } 12 \\
\text { months }\end{array}$ & $\begin{array}{l}\text { pyrexia, chills, fatigue, rash, nausea, vomiting, } \\
\text { diarrhea, abdominal pain, peripheral edema, } \\
\text { cough, headache, arthralgia, night sweats, } \\
\text { decreased appetite, constipation, and myalgia }\end{array}$ \\
\hline \multirow[t]{2}{*}{$\begin{array}{l}\text { Ascierto } \\
2013\end{array}$} & \multirow[t]{2}{*}{ Phase II } & \multirow[t]{2}{*}{71} & \multirow[t]{2}{*}{ MEK } & $\mathrm{BRAF}^{\mathrm{V} 600}$ mut & \multirow[t]{2}{*}{ MEK162 } & $\begin{array}{l}\text { PRR: about } 20 \% \text {, OR+SD: } \\
52 \%\end{array}$ & \multirow{2}{*}{$\begin{array}{l}\text { rash, diarrhea, acneiform dermatitis, creatine } \\
\text { phosphokinase (CK) elevation, fatigue, periphera } \\
\text { edema, central serous retinopathy-like retina } \\
\text { events. }\end{array}$} \\
\hline & & & & NRAS mut & & $\begin{array}{l}\text { PRR: about } 20 \% \text {, OR+SD: } \\
63 \%\end{array}$ & \\
\hline $\begin{array}{l}\text { Catalanotti } \\
2013\end{array}$ & Phase II & 15 & MEK & $\mathrm{BRAF}^{\mathrm{V} 600 \mathrm{e} / \mathrm{k}} \mathrm{mut}$ & Selumetinib & $\begin{array}{l}\text { ORR: about } 11 \%, \text { PFS and } \\
\text { OS: data pending }\end{array}$ & $\begin{array}{l}\text { rash, fatigue, elevated liver function tests, } \\
\text { lymphopenia, hypoalbuminemia, dyspnea, } \\
\text { cardiac function }\end{array}$ \\
\hline
\end{tabular}

through oncogenic mutations in BRAF gene. Finally, the MEK inhibition has been demonstrated to abrogate the CRAF-dependent activation of ERK in wild-type BRAF cells, contributing to reduce the chances of cutaneous adverse events [48]. Current clinical investigations have shown great promise with the combination of targeted therapies as a new effective strategy of melanoma treatment. A combined treatment with MEK and BRAF inhibitors in BRAF mutated metastatic patients showed a significant improvement of the progression-free survival rates [49], providing further support to the hypothesis that this could be the way for a better management of such melanoma cases. Actually, a number of clinical trials of trametinib in combination with other targeted drugs, whose activity is somehow interfering with the MAPK-driven tumour growth, are underway and expected to show great promise. As an example, it has been recently demonstrated that MEK inhibitors may enhance the ability of histone deacetylase (HDAC) inhibitors to induce apoptosis in tumour cells with constitutive activation of the BRAF-MEK-ERK signalling cascade both in vitro and in vivo [50].

Tables $2[9,10,49,51-54]$ and $3[9,10,49,51,55]$ report the main clinical trials with targeted agents for treatment of advanced melanoma.

\section{Mechanisms of Resistance to MAPK-Targeted Therapy.}

Although the antitumor effects of target therapy are striking, intrinsic and acquired resistance limits the therapeutic benefit of this approach [6,56]. On this regard, is it to be underlined that vast majority of data about such an issue is related to the resistance to BRAF inhibitors, since vemurafenib and dabrafenib have been the most extensively studied, both preclinically and clinically. cardiac function 
Citation: Colombino M, Sini MC, Lissia A, Cossu A, Palmieri G (2014) Targeted Therapies in Melanoma: Knowledge, Resistance and

Page 5 of 12

\begin{tabular}{|l|l|l|l|l|l|l|l|}
\hline $\begin{array}{l}\text { Carvajal } \\
2013\end{array}$ & Phase II & 48 & MEK & GNAQ mut & Selumetinib & $\begin{array}{l}\text { ORR: about 15\%, PFS and } \\
\text { OS: data pending }\end{array}$ & $\begin{array}{l}\text { CPK elevation, LFT elevation, rash, lymphopenia, } \\
\text { edema }\end{array}$ \\
\hline
\end{tabular}

Table 2: Targeted therapy single agents and combinatorial testing in melanoma

\section{Intrinsic resistance}

Approximately $20 \%$ of patients with BRAF mutated melanoma tumours are not responsive to the treatment at all (vemurafenib or drabafenib) due to intrinsic resistance [13]. Because melanoma exhibits a wide spectrum of tumour-associated genomic lesions and a high degree of inter- and intratumoral heterogeneity, the mechanisms of intrinsic resistance to RAF inhibitors are likely to be diverse:

Gene amplification and/or overexpression of Cyclin D1, which contrasts the activity of the cyclin-dependent kinase inhibitor p16CDKN2A and stimulates the CyclinD1-RB pathway [57] (Table 3);

\begin{tabular}{|c|c|c|c|c|c|c|c|c|}
\hline Reference & Targeted therapy & $\begin{array}{l}\text { Number of } \\
\text { patients } \\
\text { (ratio) }\end{array}$ & Patient population & $\begin{array}{l}\text { Response rate } \\
(95 \% \mathrm{Cl})\end{array}$ & $\begin{array}{l}\text { Median } \\
\text { PFS }\end{array}$ & Median OS & $\begin{array}{l}\text { 6-month } \\
\text { OS rate }\end{array}$ & $\begin{array}{l}\text { 12-month } \\
\text { OS rate }\end{array}$ \\
\hline \multirow{2}{*}{$\begin{array}{l}\text { Chapman } \\
2011\end{array}$} & Vemurafenib & \multirow[t]{2}{*}{$675(1: 1)$} & \multirow[t]{2}{*}{ Previously untreated } & $48 \%(42-55)$ & 6.9 months & 13.6 months & $84 \%$ & $56 \%$ \\
\hline & Dacarbazine & & & $5 \%(3-9)$ & 1.6 months & 9.7 months & $64 \%$ & $44 \%$ \\
\hline \multirow{2}{*}{$\begin{array}{l}\text { Hauschild } \\
2012\end{array}$} & Dabrafenib & \multirow[t]{2}{*}{$250(3: 1)$} & \multirow{2}{*}{$\begin{array}{l}\text { Previously } \\
\text { untreated } \\
\text { (except HD IL-2) }\end{array}$} & $50 \%(42-57)$ & 5.1 months & 18.2 months & NR & NR \\
\hline & Dacarbazine & & & $6 \%(2-16)$ & 2.7 months & 15.6 months & $N R$ & NR \\
\hline \multirow[t]{2}{*}{ Robert 2012} & Trametinib & \multirow[t]{2}{*}{$322(2: 1)$} & \multirow{2}{*}{$\begin{array}{l}\text { One previous treatment } \\
\text { allowed, except BRAF or } \\
\text { MEK } \\
\text { inhibitors or ipilimumab }\end{array}$} & $22 \%(17-22)$ & 4.8 months & NR & $81 \%$ & NR \\
\hline & Dacarbazine or paclitaxel & & & $8 \%(4-15)$ & 1.5 months & NR & $67 \%$ & NR \\
\hline \multirow[t]{3}{*}{$\begin{array}{l}\text { Flaherty } \\
2012\end{array}$} & $\begin{array}{l}\text { Dabrafenib+trametinib } \quad(150 \\
\mathrm{mg} / 1 \mathrm{mg})\end{array}$ & \multirow[t]{3}{*}{$247(1: 1: 1)$} & \multirow{3}{*}{$\begin{array}{l}\text { One previous treatment } \\
\text { allowed, except BRAF } \\
\text { inhibitor }\end{array}$} & $50 \%(36-64)$ & 9,2 months & NR & NR & $26 \%$ \\
\hline & $\begin{array}{l}\text { Dabrafenib+trametinib } \quad(150 \\
\mathrm{mg} / 2 \mathrm{mg})\end{array}$ & & & $76 \%(62-86)$ & 9.4 months & NR & NR & $41 \%$ \\
\hline & Dabrafenib & & & $54 \%(40-67)$ & 5.8 months & NR & NR & $9 \%$ \\
\hline \multirow[t]{2}{*}{ Robert 2012} & Selumetinib+Dacarbazina & \multirow[t]{2}{*}{$91(1: 1)$} & \multirow[t]{2}{*}{ Previously untreated } & $40 \%(18-45)$ & 5.6 months & 13.9 months & $40 \%$ & NR \\
\hline & Dacarbazina & & & $26 \%(12-46)$ & 3 months & 10.3 months & $22 \%$ & NR \\
\hline
\end{tabular}

Table 3: Summary of phaseII/III randomized trials for melanoma

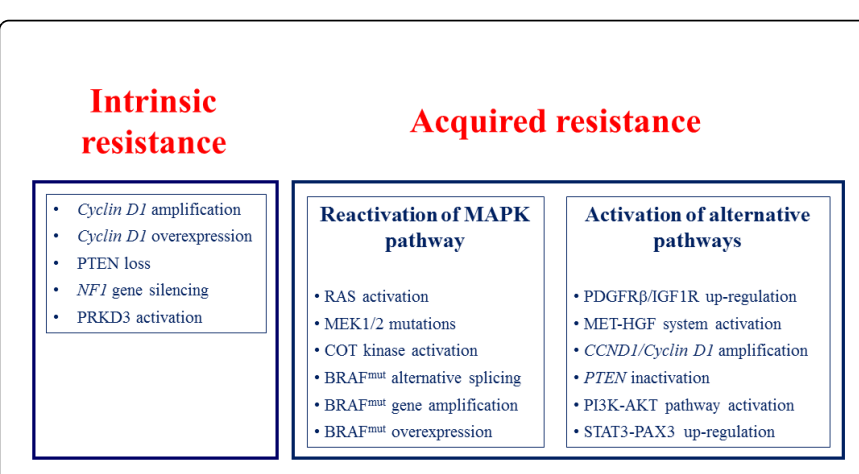

Figure 1: Main known mechanisms (intrinsic and acquired) by which BRAF mutant cells develops drug resistance against RAF and MEK inhibitors.

- Less of PTEN tumour suppressor protein and consequent increased basal level of AKT signalling [58];

- Silencing of the NF1 gene, which either promotes RAS activation either impairs the mechanisms regulating the senescence process controlling the cell proliferation [59];
- Increased activity of protein kinase D3 (PRKD3), with activation of the PI3K-AKT signalling in presence of a specific inhibition of the oncogenic BRAF [60].

Figure 1 summarizes the different resistance mechanisms which are preexistent (giving an intrinsic refractoriness) or activated following the drug administration (favoring the block escape in a MAPKdependent or MAPK-independent manner) to the treatment with inhibitors of the RAS-RAF-MEK-ERK pathway.

To better understand the reasons why all these apparently different molecular alterations are implicated in conferring resistance to BRAF or MEK inhibitors in melanoma cells, it is necessary to keep in mind the relationship between RAF/MEK/ERK activation and melanomagenesis. As is common knowledge, oncogenic BRAF mutant strongly stimulates cell cycle progression by activation of downstream MEK/ERK pathway. However, the BRAF-driven melanocytic proliferation needs the coexistence of alterations in additional cellcycle factors (such as p53 deficiency, genetic/epigenetic inactivation of p16CDKN2A gene, increased levels of active AKT) in order to promote melanoma growth and progression [61]. In a subset of melanomas, such additional pathogenetic alterations acquire a prevalent role and tumour cell proliferation becomes independent or less dependent on activation of BRAF/MEK/ERK pathway. 
Independently from the functional status BRAF/MEK/ERK pathway, overexpression of Cyclin D1 may drive cell cycle entry and uncontrolled growth: increased Cyclin D1 protein expression determines a marked increase in activating bind to the CDK4/6 kinases and in phosphorylation of the RB protein. In support of this overexpression experiments showed that introduction of Cyclin D1 into previously drug sensitive cell lines did facilitate cell cycle entry and proliferation even when BRAF was inhibited [57].

As mentioned above, the loss of PTEN function results in accumulation of PIP3 mimicking the effect of PI3K activation and triggering the activation of its downstream effectors like AKT. Hyperactivated AKT has been shown to promote cell proliferation, possibly through down-regulation of the cyclin-dependent kinase inhibitor p27 and the up-regulation of Cyclins E and D1 [62,63]. Differential mechanisms of AKT activation demand an upstream PI3K activation, since activating mutations of AKT are nearly absent in melanoma (only rare mutations in AKT1 and AKT3 genes have been indeed reported in a limited number of melanomas and melanoma cell lines [64-66]). On this regard, the PI3K signalling seems to be directly increased by the occurrence of activating mutations in its kinase domain [67].

AKT regulates the apoptotic response to a variety of stimuli via its ability to interact with a number of key players in the apoptotic process, its intracellular accumulation does result in the suppression of apoptosis and induction of cell survival [64]. AKT can directly phosphorylate BAD (Bcl-2 antagonist of cell death) and MDM2; in turn, BAD inactivation affects the interaction of this protein with with anti-apoptotic members of the Bcl-2 family of proteins (Bcl-2, Bcl-XL) [68-69] and MDM2 leads to increases p53 degradation [70,71]. In addition, the increase in AKT signalling suppresses the expression of BIM (pro-apoptotic member of $\mathrm{Bcl}-2$ protein family), with inhibition of its pro-apoptotic activity [72]: the expression levels of BIM protein is indeed regulated by silencing of PTEN and subsequent activation of the PI3K-AKT pathway in conjunction with the activation of BRAF/MEK/ERK pathway [73]. The presence of PTEN inactivation may therefore interfere with the BRAF inhibition by reducing the levels of BIM protein and, thus, the extent of apoptotic induction; as a confirmation of this, a simultaneous treatment with BRAF and PI3K inhibitors has been reported to enhance BIM expression and increase the level of induced apoptosis [58].

Hence, the occurrence of a p53 deficiency or, more in general, a status of apoptosis escape, with an unbalanced ratio between pro- and anti-apoptotic effectors-all events found to cooperate with BRAF mutations in driving the melanoma progression [74-75]-may induce a MAPK-independent tumour growth [76]. Inactivation of AKT by targeting PI3K has been also demonstrated to effectively inhibit cell proliferation [58,77]. The combination of a BRAF or MEK inhibitor with a PI3K/mTOR inhibitor was found to enhance cell growth inhibition through achievement of ERK hypophosphorylation, reduced Cyclin D1 levels and increased p27 levels, overcoming the resistance encountered by the use of a single anti-BRAF or anti-MEK agent $[44,78]$. Amplification of Cyclin D1, allelic deletions downregulating p16CDKN2A, and alterations inactivating PTEN have been all associated with a poorer progression-free survival following treatment with dabrafenib in patients with BRAF-mutant metastatic melanoma [79].

The protein encoded by the NF1 gene, neurofibromin, is a known tumour suppressor gene and negative regulator of RAS protein. Therefore, loss of NF1 mediates resistance to RAF and MEK inhibitors trough sustained MAPK pathway activation [59]. Recent studies have shown how NF1 ablation decreases the sensitivity to BRAF inhibitors in BRAF mutant melanoma cells that are intrinsically resistant to BRAF inactivation as well as in melanomas developing resistance to vemurafenib $[59,80]$.

Finally, activation of PRKD3 (protein kinase D3) contribute to resistance to such target therapies by direct stimulating the PI3K-AKT pathway. Inhibition of this gene has been reported to enhance cell growth arrest by BRAF and MEK inhibitors and enforce cell sensitivity to these agents [60]. The NF1 loss and the PRKD3 activation can be considered as key mediators of both acquired and intrinsic BRAF inhibitor resistance (increased activity of PRKD3 seems to however confer resistance to RAF265 rather than approved BRAF inhibitors $[60])$.

\section{Acquired resistance}

Although very encouraging, the clinical responses to BRAF inhibitors are relatively short-lived and resistance to treatment develops in 6 to 8 months from the initiation of therapy, with treatment failure and tumour progression occurring in nearly every case. In contrast with several studies that shown how acquired drug resistance was associated with the acquisition of secondary mutations in kinase being targeted that prevented the binding of drug (for example T790M in the EGR receptor [81] and T315I in Bcr-ABL [82]), secondary BRAF mutations were not the mechanism of resistance in melanomas patients [40]. The emerging data instead suggest that a diverse array of BRAF inhibitor acquired resistance mechanisms exists and they are highly heterogeneous [83].

At a glance, two different pathogenetic scenarios of acquired resistance may be depicted (Figure 1).

The first scenario include mechanisms underlying reactivation of the RAS/RAS/MEK/ERK pathway trough induced alterations in components of this signalling cascade: activation of RAS signalling [84], activating mutations in MAP2K1 (encoding MEK1 protein) or MAP2K2 (encoding MEK2 protein) genes [85,86], activation of MAPK pathway agonists such as COT kinase [87], occurrence of alternative splicing of the BRAF mutant mRNA [88], BRAF-mutated gene amplification [89]. In this case, the cell proliferation/tumour growth is still depending on RAS/BRAF/MEK/ERK cascade activity and BRAF inhibition is overcome with alternative changes within this same pathway (real failure of BRAF inhibitors).

The second scenario is represented by reactivation of the suppressed ERK signalling through induced alterations in components of cell proliferation-controlling pathways different from the BRAF/MEK/ERK cascade: up-regulation of the receptor tyrosine kinase (RTK) effectors-such as the platelet-derived growth factor receptor $\beta$ (PDGFR $\beta$ ) [90], activation of the MET-HGF system [91], amplification of the CCND1/Cyclin D1 gene or lack of PTEN function with subsequent activation of the PI3K-AKT pathway [62], enhancement of the IGF-1R/PI3K signalling [92], up-regulation of the signal transducer and activator of transcription 3 (STAT 3)-paired box homeotic gene 3 ( $P A X 3)$-signalling pathway [93-95]. In this case, BRAF inhibition is still effective, but the tumour is not anymore dependent upon RAF/MEK/ERK signalling for growth and survival (paradoxical failure of BRAF inhibitors).

As largely known, in melanoma with mutated BRAF, activation of the downstream MEK/ERK pathway is independent on the RAS- 
ligand activity and BRAF mutant transmits continuous proliferation signals acting as a RAF-inhibitor-sensitive monomer. Vemurafenib and dabrafenib potently inhibit such BRAF mutant monomers, causing markedly decreased levels of ERK phosphorylation [94]. As a consequence, the ERK-dependent feedback is progressively turned off, RAS-driven signal transduction is restored with increasing levels of active RAS-GTP, and RAF-inhibitor-resistant RAF dimers are generated. The RAF homo- or heterodimers (CRAF-CRAF, BRAF mutant-CRAF) are able to reactivate the MEK/ERK pathway with a consequent increased activity of the ERK $1 / 2$ proteins [90-96]. In preclinical models, increased activity was firstly identified in drugresistant clones derived from cell line undergoing BRAF-inhibition [97]. Occurrence of CRAF mutations has been to also contribute in reactivating the MEK-ERK axis - again, in a dimerization-dependent manner-following exposure to RAF inhibitors [98]. Enhanced RASdependent RAF dimerization has also been involved into the pathogenesis of squamous cell carcinomas, as a side effect in subsets of patients treated with RAF inhibitors $[99,100]$. These agents have been demonstrated to indeed activate MAPK pathway by inducing RAF dimerization in cells lacking BRAF mutations $[38,40,88,102]$, leading to increased keratinocyte proliferation. Enhanced RAF dimerization is also promoted by alteration such as NRAS mutations: a genetic analysis of biopsies from patients resistant to vemurafenib revealed the presence of an activating NRAS mutation (Q 61) that was lacking in the original tumours. This switch in mutational status was accompanied by the reactivation of MAPK pathway after treatment with vemurafenib [40]. Mutations in any of the three isoforms of RAS (with preponderance of those occurring in HRAS gene) may also contribute to the development of squamous cell carcinomas as adverse event during the treatment with BRAF inhibitors $[5,40]$.

Another mechanism that drives formation of RAF dimers, with consequent RAF inhibitor resistance, consists in upstream activation of receptor tyrosine kinase (RTK) MET via hepatocyte growth factor (HGF), which is its main ligand [91,103-104]. Several studies has shown how HGF, overexpressed by stromal cells of the tumour microenvironment, stimulates MET receptor promoting transduction of the signal to the downstream PI3K effector with subsequent enhancement of AKT activity [104,105]. The HGF-MET axis plays a critical role in both intrinsic and acquired resistance to BRAF inhibition; the addiction of either an inhibitor of HGF or MET simultaneously to BRAF inhibitor re-establishes sensitivity to BRAF inhibition [91]. To investigate if additional pathways were stimulated in response to chronic BRAF inhibition, the activation of several tyrosine kinase receptors (RTKs) are being examined; among them, insulin like growth factor receptor-1 (IGF-1R) has been identified as being constitutively activated in resistant cells [92]. IGF-1R can activate both the MAPK and PI3K pathways: IGF-1R signalling cooperate with MAPK pathway in regulating progression from benign nevi to malignant melanoma through sustainment of cell survival and dissemination and increase of IGF-1R expression reflects an enhanced activity of PI3K/AKT $[92,106]$. All these clues suggest the possible existence of a negative crosstalk between the two pathways during chronic BRAF inhibition. Crosstalk between MAPK and PI3K has been reported in several cancer systems, but not much is known in melanoma [107,108]. Interruption of IGF-1R signalling has been shown to inhibit tumour growth and block metastasis formation in a wide variety of tumour models and dual inhibition of IGF-1R and MEK inhibitors has been demonstrated to induce growth arrest in BRAF inhibitor-resistant cells [92]. Acquired resistance to BRAF and MEK inhibitors resistance seems to be associated with the up- regulated expression of other RTKs such as PDGFR $\beta$-receptor (platelet derived growth factor receptor): its increased expression, in BRAF-inhibitor resistant cellular models, was demonstrated to be responsible for improving cell survival and invasiveness in a manner independent on the activation of the MAPK pathway [40]. In presence of BRAF or MEK inhibitors, IFG-1R and PDGFR $\beta$ signalling has been shown to overexpress the STAT3 (transcriptional activation factor) with consequent activation of STAT3 pathway through stimulation of the Src/FAK transducers [94,109-111]. STAT 3 acts as a direct transactivator of the PAX3 promoter implicated in activating expression of the receptor tyrosine kinase MET in melanoma [112]. The importance of the STAT3-PAX3 signalling axis has been highlighted through knockdown experiments; indeed, knocking down either STAT3 or PAX3 in vemurafenib resistant BRAF mutated melanoma cells reduced cancer proliferation [93]. Conversely, upregulation of STAT 3 allows cells to become independent on the activity of the BRAF-MEK pathway and contribute to resistance to BRAF and MEK inhibitors [93-94,113]. Nearly all results about the role of the RTK effectors in resistance to such targeted treatments have been obtained in studies on melanoma cell lines; therefore, significant data from analysis of clinical samples are not yet available.

Through a functional genomics approach, expression of COT kinase was also identified as a putative mechanism of RAF inhibitor resistance: a number of melanoma cells lines and tissues showed a genomic amplification of COT associated with intrinsic BRAF and MEK inhibitor resistance [87]. The overexpression of the COT kinase, which is encoded by the MAP3K8 gene, is induced by the treatment with BRAF or MEK inhibitors acting as an agonist of the MAPK pathway and leading to resistance to BRAF-MEK inhibition [87]. The identification of COT is an example of an inhibitory bypass mechanism that results in reactivation of ERK signalling in a RAFindependent manner. However, the relevance of increased COT expression in the resistant phenotype was mainly evidenced in experimental sets but poorly confirmed in patients failing BRAF and MEK inhibitor treatment. Downstream mutations in MAP2K1 (encoding MEK1 protein) and MAP2K2 (encoding MEK 2 protein) genes have also been reported as resistance drivers to BRAF or MEK inhibitors [115]. Specially the MEK1 P124L and Q56P specific mutations have been shown to modify the allosteric pocket of MEK1, making MEK1 protein either independent on stimulation by upstream BRAF either insensitive to MEK inhibitors [85]. Further study have shown how other MEK1 mutants (e.g. P142S and I111S) respond to BRAF inhibitor treatment, suggesting that not all MEK1 mutations make BRAF-mutant melanomas resistant to BRAF inhibitors [115].

While secondary mutations in BRAF have not been identified as a cause of BRAF or MEK inhibitor resistance (see above), several studies identified selective amplification of the mutant BRAF allele as the mechanism underlying acquired resistance [116-118]. Gene mutations and copy number gains may occur independently of each other, since are determined from different pathogenetic mechanism: alterations affecting the molecular machinery that monitors the proper progression of the cell cycle seem to be responsible for the presence of gross genomic anomalies during the malignant progression (indeed, copy number gains are often the consequence of random genomic instability), whereas mutations usually occur in diploid karyotypes with few structural abnormalities during the initial phases of evolution of malignancies [119]. However, in some cases, gene amplifications tend to occur in the same cancers presenting oncogenic mutations, as reported for EGFR in NSCLC or BRAF in colorectal carcinoma [120-121]. Recent elegant study has shown how melanoma cells 
Page 8 of 12

chronically exposed to trametinib acquired concurrent MEK2-Q60P mutation and BRAF-V600E amplification, which conferred resistance to MEK and BRAF inhibitors [122].

A peculiar, qualitative mechanism of resistance is represented by the intracellular accumulation of a splice variant of the mutated BRAF mRNA. A subset of melanoma cells resistant to BRAF inhibitors express a truncated form of BRAFV600E, p61BRAFV600E, that lacks the RAS-binding domain but retain the kinase domain [88]. These BRAF splice variants dimerize in a RAS-independent manner, consistent with the model that only BRAF V600E monomers are sensitive to inhibition. The final effect of such an alteration is a transactivation of the MEK-ERK pathways, with ERK signalling being resistant to the RAF inhibitors [41,88]. Moreover, the vemurafenibresistant melanomas presenting an enhanced transcription and translation of the mutated BRAF kinase may develop a drug dependency for their continued proliferation, such that cessation of BRAF inhibitor administration may lead to regression of non-lethal drug-resistant tumours [123]. This evidence has suggested that a discontinued treatment with these agents may somehow prevent the emergence of lethal drug-resistant cell clones [123]. Although BRAF splice variants were not detected in vemurafenib-naïve patients with cancer, it is possible that they are expressed in a small subpopulation of cells within the pre-treatment tumour and that exposure to BRAF inhibitors provides a selective pressure for the propagation of the BRAF splice variant-expressing tumor population. More in general, since major genetic alterations (i.e. mutations in BRAF and NRAS) are maintained during melanoma progression [124,125], one could speculate that resistance to targeted therapies are likely due to the presence of resistant sub-clones within the primary tumors which may be induced to proliferate and expand themselves after the initiation of inhibitory therapy (Figure 2). On this regard, much debate however exists in regard to the "selection" or "acquisition" of molecular alterations conferring resistance to targeted therapies in different types of cancers. The fact that in rare instances the resistance alterations have been identified in biopsy specimens of treatment-naive patients using standard screening techniques could be indeed imputed to either the true initial absence of them or the poor sensitivity of the current analytical methods in identifying the very limited fraction of tumor cells with such under-represented alterations. Further supporting the hypothesis about the prevalence of the "selection" model of resistance alterations, a growing number of studies are suggesting that the inherent phenotypic and genetic heterogeneity of cancer cell populations in primary tumours represent a critical determinant of drug resistance $[126,127]$.

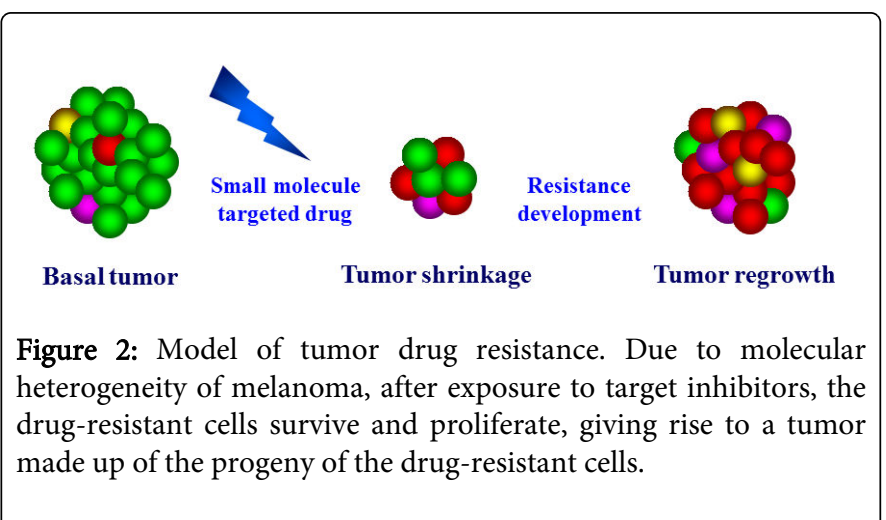

Figure 2: Model of tumor drug resistance. Due to molecular heterogeneity of melanoma, after exposure to target inhibitors, the drug-resistant cells survive and proliferate, giving rise to a tumor up of the progeny of the drug-resistant cells.

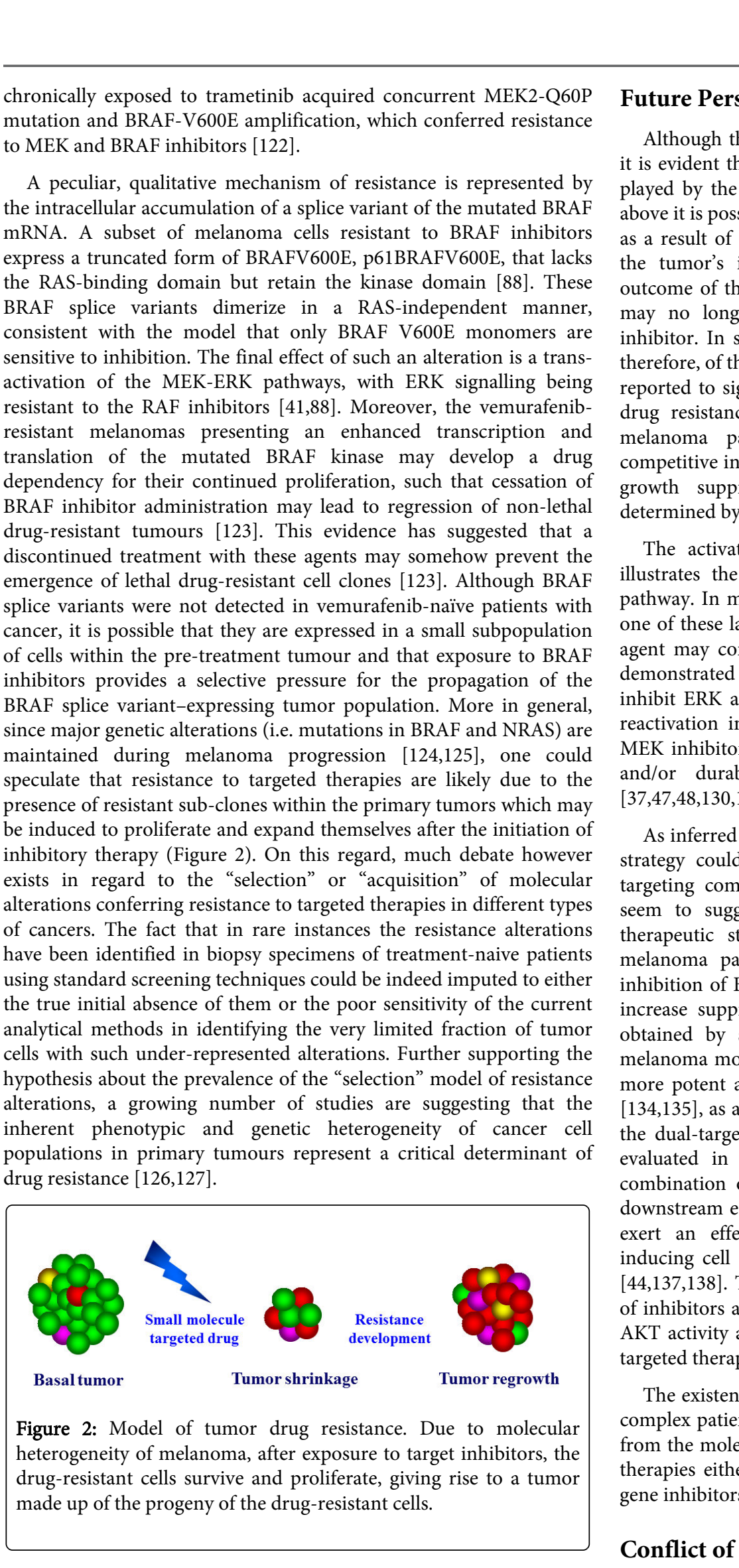

\section{Conflict of Interest}

All authors declare the absence of any Conflict of Interest. 


\section{Acknowledgments}

Work was partially supported by the Italian Ministry of Health "Progetto Ricerca Finalizzata" and Sardinia Regional Government (Regione Autonoma della Sardegna).

\section{References}

1. Davies H, Bignell GR, Cox C, Stephens P, Edkins S, et al (2002) Mutations of the BRAF gene in human cancer. Nature : 949-954.

2. Curtin JA, Fridlyand J, Kageshita T, Patel HN, Busam KJ, et al. (2005) Distinct sets of genetic alterations in melanoma. N Engl J Med 353: 2135-2147.

3. Lee JH, Choi JW, Kim YS (2011) Frequencies of BRAF and NRAS mutations are different in histological types and sites of origin of cutaneous melanoma: a meta-analysis. Br J Dermatol 164: 776-784.

4. Ascierto PA, Grimaldi AM, Acquavella N, Borgognoni L, Calabr $\tilde{A}^{2}$ L, et al (2013)Future perspectives in melanoma research. Meeting report from the "Melanoma Bridge. Napoli, December 2nd-4th 2012". J Transl Med: 137

5. Jang S, Atkins MB (2013) Which drug, and when, for patients with BRAF-mutant melanoma? Lancet Oncol 14: e60-69.

6. Sosman JA, Kim KB, Schuchter L, Gonzalez R, Pavlick AC, et al. (2012) Survival in BRAF V600-mutant advanced melanoma treated with vemurafenib. N Engl J Med 366: 707-714.

7. Jang S, Atkins MB (2013) Which drug, and when, for patients with BRAF-mutant melanoma? Lancet Oncol 14: e60-69.

8. Menzies AM, Long GV (2013) Recent advances in melanoma systemic therapy. BRAF inhibitors, CTLA4 antibodies and beyond. Eur J Cancer 49: 3229-3241.

9. Chapman PB, Hauschild A, Robert C, Haanen JB, Ascierto P, et al. (2011) Improved survival with vemurafenib in melanoma with BRAF V600E mutation. N Engl J Med 364: 2507-2516.

10. Hauschild A, Grob JJ, Demidov LV, Jouary T, Gutzmer R, et al (2012) Dabrafenib in BRAF-mutated metastatic melanoma: a multicentre, openlabel, phase 3 randomised controlled trial. Lancet: 358-365.

11. Long GV, Trefzer U, Davies MA, Kefford RF, Ascierto PA, et al (2012) Dabrafenib in patients with Val600Glu or Val600Lys BRAF-mutant melanoma metastatic to the brain (BREAK-MB): a multicentre, openlabel, phase 2 trial. Lancet Oncol: 1087-1095.

12. Menzies AM, Long GV (2013) Recent advances in melanoma systemic therapy. BRAF inhibitors, CTLA4 antibodies and beyond. Eur J Cancer 49: 3229-3241.

13. Van Allen EM, Wagle N, Sucker A, Treacy DJ, Johannessen CM, et al. (2014) The genetic landscape of clinical resistance to RAF inhibition in metastatic melanoma. Cancer Discov 4: 94-109.

14. Palmieri G, Capone M, Ascierto ML, Gentilcore G, Stroncek DF, et al. (2009) Main roads to melanoma. J Transl Med 7: 86.

15. Moodie SA, Willumsen BM, Weber MJ, Wolfman A (1993) Complexes of Ras.GTP with Raf- 1 and mitogen-activated protein kinase kinase. Science 260: 1658-1661.

16. Daub M, Jöckel J, Quack T, Weber CK, Schmitz F, et al. (1998) The $\mathrm{RafC1}$ cysteine-rich domain contains multiple distinct regulatory epitopes which control Ras-dependent Raf activation. Mol Cell Biol 18: 6698-6710.

17. Garnett MJ, Rana S, Paterson H, Barford D, Marais R (2005) Wild-type and mutant B-RAF activate C-RAF through distinct mechanisms involving heterodimerization. Mol Cell 20: 963-969.

18. Terai K, Matsuda M (2006) The amino-terminal B-Raf-specific region mediates calcium-dependent homo- and hetero-dimerization of Raf. EMBO J 25: 3556-3564.

19. Fischer A, Hekman M, Kuhlmann J, Rubio I, Wiese S, et al. (2007) B- and C-RAF display essential differences in their binding to Ras: the isotypespecific $\mathrm{N}$ terminus of B-RAF facilitates Ras binding. J Biol Chem 282: $26503-26516$
20. Downward J (2003) Targeting RAS signalling pathways in cancer therapy. Nat Rev Cancer 3: 11-22.

21. Saxena N, Lahiri SS, Hambarde S, Tripathi RP (2008) RAS: target for cancer therapy. Cancer Invest 26: 948-955.

22. Smalley KS, Eisen TG (2003) Farnesyl transferase inhibitor SCH66336 is cytostatic, pro-apoptotic and enhances chemosensitivity to cisplatin in melanoma cells. Int J Cancer 105: 165-175.

23. End DW, Smets G, Todd AV, Applegate TL, Fuery CJ, et al (2001) Characterization of the antitumor effects of the selective farnesyl protein transferase inhibitor R115777 in vivo and in vitro. Cancer Res: 131-137

24. Konstantinopoulos PA, Karamouzis MV, Papavassiliou AG (2007) Posttranslational modifications and regulation of the RAS superfamily of GTPases as anticancer targets. Nat Rev Drug Discov 6: 541-555.

25. Gajewski TF, Salama AK, Niedzwiecki D, Johnson J, Linette G, et al. (2012) Phase II study of the farnesyltransferase inhibitor R115777 in advanced melanoma (CALGB 500104). J Transl Med 10: 246.

26. 26. Niessner H, Beck D, Sinnberg T, Lasithiotakis K, Maczey E, et al (2011) The farnesyl transferase inhibitor lonafarnib inhibits mTOR signalling and enforces sorafenib-induced apoptosis in melanoma cells. J Invest Dermatol: 468-479

27. Flaherty KT (2007) Sorafenib: delivering a targeted drug to the right targets. Expert Rev Anticancer Ther 7: 617-626.

28. Eisen T, Ahmad T, Flaherty KT, Gore M, Kaye S, et al (2006) Sorafenib in advanced melanoma: a Phase II randomised discontinuation trial analysis. Br J Cancer: 581-586.

29. Hauschild A, Agarwala SS, Trefzer U, Hogg D, Robert C, Hersey P, et al. (2009) Results of a phase III, randomized, placebo-controlled study of sorafenib in combination with carboplatin and paclitaxel as second-line treatment in patients with unresectable stage III or stage IV melanoma. J Clin Oncol : 2823-2830

30. McDermott DF, Sosman JA, Gonzalez R, Hodi FS, Linette GP, et al. (2008) Double-blind randomized phase II study of the combination of sorafenib and dacarbazine in patients with advanced melanoma: a report from the 11715 Study Group. J Clin Oncol :2178- 2185

31. Lee JT, Li L, Brafford PA, van den Eijnden M, Halloran MB, et al. (2010) PLX4032, a potent inhibitor of the B-Raf V600E oncogene, selectively inhibits V600E-positive melanomas. Pigment Cell Melanoma Res 23: 820-827.

32. Chapman PB, Hauschild A, Robert C, Haanen JB, Ascierto P, et al. (2011) Improved survival with vemurafenib in melanoma with BRAF V600E mutation. N Engl J Med 364: 2507-2516.

33. Hauschild A, Grob JJ, Demidov LV, Jouary T, Gutzmer R, et al. (2012) Dabrafenib in BRAF-mutated metastatic melanoma: a multicentre, openlabel, phase 3 randomised controlled trial. Lancet: $358-365$

34. Gentilcore G, Madonna G, Mozzillo N, Ribas A, Cossu A, et al. (2013) Effect of dabrafenib on melanoma cell lines harbouring the BRAF(V600D/R) mutations. BMC Cancer 13: 17.

35. Ascierto PA, Minor D, Ribas A, Lebbe C, O'Hagan A, et al. (2013) Phase II trial (BREAK-2) of the BRAF inhibitor dabrafenib (GSK2118436) in patients with metastatic melanoma. J Clin Oncol 31: 3205-3211.

36. Salama AK, Flaherty KT (2013) BRAF in melanoma: current strategies and future directions. Clin Cancer Res 19: 4326-4334.

37. King AJ, Arnone MR, Bleam MR, Moss KG, Yang J, et al. (2013) Dabrafenib; preclinical characterization, increased efficacy when combined with trametinib, while BRAF/MEK tool combination reduced skin lesions. PLoS One: e67583

38. Hatzivassiliou G, Song K, Yen I, Brandhuber BJ, Anderson DJ, et al. (2010) RAF inhibitors prime wild-type RAF to activate the MAPK pathway and enhance growth. Nature 464: 431-435.

39. Heidorn SJ, Milagre C, Whittaker S, Nourry A, Niculescu-Duvas I, et al. (2010) Kinase-dead BRAF and oncogenic RAS cooperate to drive tumor progression through CRAF. Cell 140: 209-221.

40. Nazarian R, Shi H, Wang Q, Kong X, Koya RC, et al. (2010) Melanomas acquire resistance to B-RAF(V600E) inhibition by RTK or N-RAS upregulation. Nature 468: 973-977. 
41. Poulikakos PI, Zhang C, Bollag G, Shokat KM, Rosen N (2010) RAF inhibitors transactivate RAF dimers and ERK signalling in cells with wild-type BRAF. Nature 464: 427-430.

42. Yoon J, Koo KH, Choi KY (2011) MEK1/2 inhibitors AS703026 and AZD6244 may be potential therapies for KRAS mutated colorectal cancer that is resistant to EGFR monoclonal antibody therapy. Cancer Res 71: 445-453.

43. Hatzivassiliou G, Haling JR, Chen H, Song K, Price S, et al. (2013) Mechanism of MEK inhibition determines efficacy in mutant KRASversus BRAF-driven cancers. Nature 501: 232-236.

44. Greger JG, Eastman SD, Zhang V, Bleam MR, Hughes AM, et al. (2012) Combinations of BRAF, MEK, and PI3K/mTOR inhibitors overcome acquired resistance to the BRAF inhibitor GSK2118436 dabrafenib, mediated by NRAS or MEK mutations. Mol Cancer Ther 11: 909-920.

45. Kim KB, Kefford R, Pavlick AC, Infante JR, Ribas A, et al. (2013) Phase II study of the MEK1/MEK2 inhibitor Trametinib in patients with metastatic BRAF-mutant cutaneous melanoma previously treated with or without a BRAF inhibitor. J Clin Oncol: 482-489

46. Catalanotti F, Solit DB, Pulitzer MP, Berger MF, Scott SN, et al. (2013) Phase II trial of MEK inhibitor selumetinib (AZD6244, ARRY-142886) in patients with BRAFV600E/K-mutated melanoma. Clin Cancer Res 19: 2257-2264.

47. Byron SA, Loch DC, Wellens CL, Wortmann A, Wu J, et al. (2012) Sensitivity to the MEK inhibitor E6201 in melanoma cells is associated with mutant BRAF and wildtype PTEN status. Mol Cancer 11: 75.

48. King AJ, Arnone MR, Bleam MR, Moss KG, Yang J, et al. (2013) Dabrafenib; preclinical characterization, increased efficacy when combined with trametinib, while BRAF/MEK tool combination reduced skin lesions. PLoS One: e67583

49. Flaherty KT, Infante JR, Daud A, Gonzalez R, Kefford RF, et al. (2012) Combined BRAF and MEK inhibition in melanoma with BRAF V600 mutations. N Engl J Med 367: 1694-1703.

50. Sakamoto T, Ozaki K, Fujio K, Kajikawa SH, Uesato S, et al.(2013) Blockade of the ERK pathway enhances the therapeutic efficacy of the histone deacetylase inhibitor MS-275 in human tumour xenograft models. Biochem Biophys Res Commun: 456-462

51. Robert C, Flaherty KT, Hersey P, Nathan PD, Garbe C, et al. (2012) METRIC phase III study: Efficacy of trametinib (T), a potent and selective MEK inhibitor (MEKi), in progression-free survival (PFS) and overall survival (OS) compared with chemotherapy $(\mathrm{C})$ in patients (pts) with BRAFV600/k mutant advanced or metastatic melanoma (MM). Clin Oncol, 2012 ASCO Annual Meeting

52. Ascierto PA, Schadendorf D, Berking C, Agarwala SS, van Herpen CM, et al. (2013) MEK162 for patients with advanced melanoma harbouring NRAS or Val600 BRAF mutations: a non-randomised, open-label phase 2 study. Lancet Oncol 14: 249-256.

53. Catalanotti F, Solit DB, Pulitzer MP, Berger MF, Scott SN, et al. (2013) Phase II trial of MEK inhibitor selumetinib (AZD6244, ARRY-142886) in patients with BRAFV600E/K-mutated melanoma. Clin Cancer Res 19: 2257-2264.

54. Carvajal RD, Sosman JA, Quevedo F, Milhem MM, Joshua AM, et al. (2013) Phase II study of selumetinib (sel) versus temozolomide (TMZ) in gnaq/Gnal1 (Gq/11) mutant (mut) uveal melanoma (UM). J Clin Oncol 31, 2013 ASCO Annual Meeting

55. Robert C, Dummer R, Gutzmer R, Lorigan P, Kim KB, et al. (2013) Selumetinib plus dacarbazine versus placebo plus dacarbazine as first-line treatment for BRAF-mutant metastatic melanoma: a phase 2 doubleblind randomised study. Lancet Oncol: 733-740.

56. Flaherty KT, Puzanov I, Kim KB, Ribas A, McArthur GA, et al. (2010) Inhibition of mutated, activated BRAF in metastatic melanoma. $\mathrm{N}$ Engl Med 363: 809-819.

57. Smalley KS, Lioni M, Dalla Palma M, Xiao M, Desai B, et al. (2008) Increased cyclin D1 expression can mediate BRAF inhibitor resistance in BRAF V600E-mutated melanomas. Mol Cancer Ther 7: 2876-2883.
58. Paraiso KH, Xiang Y, Rebecca VW, Abel EV, Chen YA, et al. (2011) PTEN loss confers BRAF inhibitor resistance to melanoma cells through the suppression of BIM expression. Cancer Research: 2750-2760

59. Whittaker SR, Theurillat JP, Van Allen E, Wagle N, Hsiao J, et al. (2013) A genome-scale RNA interference screen implicates NF1 loss in resistance to RAF inhibition. Cancer Discov 3: 350-362.

60. Chen J, Shen Q, Labow M, Gaither LA (2011) Protein kinase D3 sensitizes RAF inhibitor RAF265 in melanoma cells by preventing reactivation of MAPK signaling. Cancer Res 71: 4280-4291.

61. Thompson JF, Scolyer RA, Kefford RF (2005) Cutaneous melanoma. Lancet 365: 687-701.

62. Carlino MS, Gowrishankar K, Saunders CA, Pupo GM, Snoyman S, et al (2013). Antiproliferative Effects of Continued Mitogen-Activated Protein Kinase Pathway Inhibition following Acquired Resistance to BRAF and/or MEK Inhibition in Melanoma. Mol Cancer Ther: 1332-1342

63. Blume-Jensen P, Hunter T (2001) Oncogenic kinase signalling. Nature 411: 355-365.

64. Plas DR, Thompson CB (2005) Akt-dependent transformation: there is more to growth than just surviving. Oncogene 24: 7435-7442.

65. Davies MA, Stemke-Hale K, Tellez C, Calderone TL, Deng W, et al. (2008) A novel AKT3 mutation in melanoma tumours and cell lines. Br J Cancer 99: 1265-1268.

66. Waldmann V, Wacker J, Deichmann M (2002) Absence of mutations in the pleckstrin homology $(\mathrm{PH})$ domain of protein kinase $\mathrm{B}(\mathrm{PKB} / \mathrm{Akt})$ in malignant melanoma. Melanoma Res 12: 45-50.

67. Shull AY, Latham-Schwark A, Ramasamy P, Leskoske K, Oroian D, et al. (2012) Novel somatic mutations to PI3K pathway genes in metastatic melanoma. PLoS One 7: e43369.

68. del Peso L, González-García M, Page C, Herrera R, Nuñez G (1997) Interleukin-3-induced phosphorylation of $\mathrm{BAD}$ through the protein kinase Akt. Science 278: 687-689.

69. Sakamaki J, Daitoku H, Ueno K, Hagiwara A, Yamagata K, et al. (2011) Arginine methylation of BCL-2 antagonist of cell death (BAD) counteracts its phosphorylation and inactivation by Akt. Proc Natl Acad Sci U S A 108: 6085-6090.

70. Mayo LD, Donner DB (2001) A phosphatidylinositol 3-kinase/Akt pathway promotes translocation of Mdm2 from the cytoplasm to the nucleus. Proc Natl Acad Sci U S A 98: 11598-11603.

71. Gottlieb TM, Leal JF, Seger R, Taya Y, Oren M (2002) Cross-talk between Akt, p53 and Mdm2: possible implications for the regulation of apoptosis. Oncogene:1299-1303

72. Dijkers PF1, Medema RH, Lammers JW, Koenderman L, Coffer PJ (2000) Expression of the pro-apoptotic Bcl-2 family member Bim is regulated by the forkhead transcription factor FKHR-L1. Curr Biol 10: 1201-1204.

73. Cartlidge RA, Thomas GR, Cagnol S, Jong KA, Molton SA, et al. (2008) Oncogenic BRAF(V600E) inhibits BIM expression to promote melanoma cell survival. Pigment Cell Melanoma Res 21: 534-544.

74. Patton EE, Widlund HR, Kutok JL, Kopani KR, Amatruda JF, et al.(2005) BRAF mutations are sufficient to promote nevi formation and cooperate with p53 in the genesis of melanoma. Curr Biol: 249-254

75. Yu H, McDaid R, Lee J, Possik P, Li L, et al. (2009) The role of BRAF mutation and p53 inactivation during transformation of a subpopulation of primary human melanocytes. Am J Pathol 174: 2367-2377.

76. Shao Y, Aplin AE (2010) Akt3-mediated resistance to apoptosis in BRAF-targeted melanoma cells. Cancer Res 70: 6670-6681.

77. Arcaro A, Guerreiro AS (2007) The phosphoinositide 3-kinase pathway in human cancer: genetic alterations and therapeutic implications. Curr Genomics: 271-306

78. Mao M, Tian F, Mariadason JM, Tsao CC, Lemos R Jr, et al. (2013) Resistance to BRAF inhibition in BRAF-mutant colon cancer can be overcome with PI3K inhibition or demethylating agents. Clin Cancer Res 19: 657-667.

79. Nathanson KL, Martin AM, Wubbenhorst B, Greshock J, Letrero R, et al. (2013) Tumor genetic analyses of patients with metastatic melanoma 
treated with the BRAF inhibitor Dabrafenib (GSK2118436). Clin Cancer Res: $4868-4878$

80. Maertens O, Johnson B, Hollstein P, Frederick DT, Cooper ZA, et al. (2013) Elucidating distinct roles for NF1 in melanomagenesis. Cancer Discov 3: 338-349.

81. Uramoto H, Shimokawa H, Hanagiri T, Kuwano M, Ono M (2011) Expression of selected gene for acquired drug resistance to EGFR-TKI in lung adenocarcinoma. Lung Cancer 73: 361-365.

82. Pricl S, Fermeglia M, Ferrone M, Tamborini E (2005) T315I-mutated $\mathrm{Bcr}-\mathrm{Abl}$ in chronic myeloid leukemia and imatinib: insights from a computational study. Mol Cancer Ther 4: 1167-1174.

83. Solit D, Sawyers CL (2010) Drug discovery: How melanomas bypass new therapy. Nature 468: 902-903.

84. Lito P, Pratilas CA, Joseph EW, Tadi M, Halilovic E, et al. (2012) Relief of profound feedback inhibition of mitogenic signalling by RAF inhibitors attenuates their activity in BRAF V600E melanomas. Cancer Cell: 668-682

85. Emery CM, Vijayendran KG, Zipser MC, Sawyer AM, Niu L, et al. (2009) MEK1 mutations confer resistance to MEK and B-RAF inhibition. Proc Natl Acad Sci U S A 106: 20411-20416.

86. Wagle N, Emery C, Berger MF, Davis MJ, Sawyer A, et al. (2011) Dissecting therapeutic resistance to RAF inhibition in melanoma by tumor genomic profiling. J Clin Oncol 29: 3085-3096.

87. Johannessen CM, Boehm JS, Kim SY, Thomas SR, Wardwell L, et al (2010) COT drives resistance to RAF inhibition through MAP kinase pathway reactivation. Nature:968-972

88. Poulikakos PI, Persaud Y, Janakiraman M, Kong X, Ng C, et al. (2011) RAF inhibitor resistance is mediated by dimerization of aberrantly spliced BRAF(V600E). Nature 480: 387-390.

89. Shi H, Moriceau G, Kong X, Lee MK, Lee H, et al. (2012) Melanoma whole-exome sequencing identifies (V600E)B-RAF amplificationmediated acquired B-RAF inhibitor resistance. Nat Commun 3: 724.

90. Nazarian R, Shi H, Wang Q, Kong X, Koya RC, et al. (2010) Melanomas acquire resistance to B-RAF(V600E) inhibition by RTK or N-RAS upregulation. Nature 468: 973-977.

91. Straussman R, Morikawa T, Shee K, Barzily-Rokni M, Qian ZR, et al. (2012) Tumour micro-environment elicits innate resistance to RAF inhibitors through HGF secretion. Nature: 500-504

92. Villanueva J, Vultur A, Lee JT, Somasundaram R, Fukunaga-Kalabis M, et al. (2010) Acquired resistance to BRAF inhibitors mediated by a RAF kinase switch in melanoma can be overcome by co-targeting MEK and IGF-1R/PI3K. Cancer Cell: 683-695

93. Liu F, Cao J, Wu J, Sullivan K, Shen J, et al. (2013) Stat3-targeted therapies overcome the acquired resistance to vemurafenib in melanomas. J Invest Dermatol 133: 2041-2049.

94. Vultur A, Villanueva J1, Krepler C1, Rajan G1, Chen Q1, et al. (2014) MEK inhibition affects STAT3 signaling and invasion in human melanoma cell lines. Oncogene 33: 1850-1861.

95. Mandalà M, Voit C (2013) Targeting BRAF in melanoma: biological and clinical challenges. Crit Rev Oncol Hematol 87: 239-255.

96. Kaplan FM, Kugel CH 3rd, Dadpey N, Shao Y, Abel EV, et al. (2012) SHOC2 and CRAF mediate ERK1/2 reactivation in mutant NRASmediated resistance to RAF inhibitor. J Biol Chem 287: 41797-41807.

97. Montagut C, Sharma SV, Shioda T, McDermott U, Ulman M, et al. (2008) Elevated CRAF as a potential mechanism of acquired resistance to BRAF inhibition in melanoma. Cancer Res 68: 4853-4861.

98. Antony R, Emery CM, Sawyer AM, Garraway LA (2013) C-RAF mutations confer resistance to RAF inhibitors. Cancer Res 73: 4840-4851.

99. Arnault JP, Wechsler J, Escudier B, Spatz A, Tomasic G, et al. (2009) Keratoacanthomas and squamous cell carcinomas in patients receiving sorafenib. J Clin Oncol 27: e59-61.

100. Arkenau HT, Kefford R, Long GV (2011) Targeting BRAF for patients with melanoma. Br J Cancer 104: 392-398.
101. Romano E, Schwartz GK, Chapman PB, Wolchock JD, Carvajal RD (2011) Treatment implications of the emerging molecular classification system for melanoma. Lancet Oncol 12: 913-922.

102. Heidorn SJ, Milagre C, Whittaker S, Nourry A, Niculescu-Duvas I, et al. (2010) Kinase-dead BRAF and oncogenic RAS cooperate to drive tumor progression through CRAF. Cell 140: 209-221.

103. Vergani E, Vallacchi V, Frigerio S, Deho P, Mondellini P, et al. (2011) Identification of MET and SRC activation in melanoma cell lines showing primary resistance to PLX4032. Neoplasia 13: 1132-1142.

104. Wilson TR, Fridlyand J, Yan Y, Penuel E, Burton L, et al. (2012) Widespread potential for growth-factor-driven resistance to anticancer kinase inhibitors. Nature 487: 505-509.

105. Olson OC, Joyce JA (2013) Microenvironment-mediated resistance to anticancer therapies. Cell Res 23: 179-181.

106. Ucar DA, Kurenova E, Garrett TJ, Cance WG, Nyberg C, et al. (2012) Disruption of the protein interaction between FAK and IGF-1R inhibits melanoma tumor growth. Cell Cycle 11: 3250-3259.

107. Carracedo A, Ma L, Teruya-Feldstein J, Rojo F, Salmena L, et al. (2008) Inhibition of mTORC1 leads to MAPK pathway activation through a PI3K-dependent feedback loop in human cancer. J Clin Invest 118: 3065-3074.

108. Cheung M, Sharma A, Madhunapantula SV, Robertson GP (2008) Akt3 and mutant V600E B-Raf cooperate to promote early melanoma development. Cancer Res 68: 3429-3439.

109. Zong CS, Chan J, Levy DE, Horvath C, Sadowski HB, et al. (2000) Mechanism of STAT3 activation by insulin-like growth factor I receptor. J Biol Chem 275: 15099-15105.

110. Wang YZ, Wharton W, Garcia R, Kraker A, Jove R, et al. (2000) Activation of Stat3 preassembled with platelet-derived growth factor beta receptors requires Src kinase activity. Oncogene 19: 2075-2085.

111. Dudka AA, Sweet SM, Heath JK (2010) Signal transducers and activators of transcription-3 binding to the fibroblast growth factor receptor is activated by receptor amplification. Cancer Res 70: 3391-3401.

112. Mascarenhas JB, Littlejohn EL, Wolsky RJ, Young KP, Nelson M, et al. (2010) PAX3 and SOX10 activate MET receptor expression in melanoma. Pigment Cell Melanoma Res 23: 225-237.

113. Dai B, Meng J, Peyton M, Girard L, Bornmann WG, et al. (2011) STAT3 mediates resistance to MEK inhibitor through microRNA miR-17. Cancer Res 71: 3658-3668.

114. Hodis E, Watson IR, Kryukov GV, Arold ST, Imielinski M, Theurillat JP, et al. (2012) A landscape of driver mutations in melanoma. Cell: 251-263

115. Shi H, Moriceau G, Kong X, Koya RC, Nazarian R, et al. (2012) Preexisting MEK1 exon 3 mutations in V600E/KBRAF melanomas do not confer resistance to BRAF inhibitors. Cancer Discov 2: 414-424.

116. Corcoran RB, Dias-Santagata D, Bergethon K, Iafrate AJ, Settleman J, et al. (2010) BRAF gene amplification can promote acquired resistance to MEK inhibitors in cancer cells harboring the BRAF V600E mutation. Sci Signal 3: ra84.

117. Villanueva J, Infante JR, Krepler C, Reyes-Uribe P, Samanta M, et al. (2013) Concurrent MEK2 mutation and BRAF amplification confer resistance to BRAF and MEK inhibitors in melanoma. Cell Rep 4: 1090-1099.

118. Little AS, Balmanno K, Sale MJ, Newman S, Dry JR, et al. (2011) Amplification of the driving oncogene, KRAS or BRAF, underpins acquired resistance to MEK1/2 inhibitors in colorectal cancer cells. Sci Signal 4: ra17.

119. Gisselsson D (2011) Mechanisms of whole chromosome gains in tumors--many answers to a simple question. Cytogenet Genome Res 133: 190-201.

120. Modrek B, Ge L, Pandita A, Lin E, Mohan S, et al. (2009) Oncogenic activating mutations are associated with local copy gain. Mol Cancer Res 7: $1244-1252$.

121. Soh J, Okumura N, Lockwood WW, Yamamoto H, Shigematsu H, et al. (2009) Oncogene mutations, copy number gains and mutant allele 
Citation: Colombino M, Sini MC, Lissia A, Cossu A, Palmieri G (2014) Targeted Therapies in Melanoma: Knowledge, Resistance and Perspectives. J Carcinog Mutagen S4: 004. doi:10.4172/2157-2518.S4-004

Page 12 of 12

specific imbalance (MASI) frequently occur together in tumor cells. PLoS One: e7464

122. Villanueva J, Infante JR, Krepler C, Reyes-Uribe P, Samanta M, et al. (2013) Concurrent MEK2 mutation and BRAF amplification confer resistance to BRAF and MEK inhibitors in melanoma. Cell Rep 4: 1090-1099.

123. Das Thakur M, Salangsang F, Landman AS, Sellers WR, Pryer NK, et al. (2013) Modelling vemurafenib resistance in melanoma reveals a strategy to forestall drug resistance. Nature 494: 251-255.

124. Omholt K, Platz A, Kanter L, Ringborg U, Hansson J.(2003) NRAS and BRAF mutations arise early during melanoma pathogenesis and are preserved throughout tumor progression. Clin Cancer Res: 6483-6488

125. Colombino M, Capone M, Lissia A, Cossu A, Rubino C, et al. (2012) BRAF/NRAS mutation frequencies among primary tumors and metastases in patients with melanoma. J Clin Oncol 30: 2522-2529.

126. Sharma SV, Lee DY, Li B, Quinlan MP, Takahashi F, et al. (2010) A chromatin-mediated reversible drug-tolerant state in cancer cell subpopulations. Cell 141: 69-80.

127. 127. Roesch A, Fukunaga-Kalabis M, Schmidt EC, Zabierowski SE, Brafford PA, et al. (2010) A temporarily distinct subpopulation of slowcycling melanoma cells is required for continuous tumour growth. Cell: 583-594.

128. Nissan MH, Rosen N, Solit DB (2013) ERK pathway inhibitors: how low should we go? Cancer Discov 3: 719-721.

129. Le K, Blomain ES, Rodeck U, Aplin AE (2013) Selective RAF inhibitor impairs ERK1/2 phosphorylation and growth in mutant NRAS, vemurafenib-resistant melanoma cells. Pigment Cell Melanoma Res 26: 509-517.

130. Paraiso KH, Fedorenko IV, Cantini LP, Munko AC, Hall M, et al. (2010) Recovery of phospho-ERK activity allows melanoma cells to escape from BRAF inhibitor therapy. Br J Cancer 102: 1724-1730.

131. Lito P, Pratilas CA, Joseph EW, Tadi M, Halilovic E, et al. (2012) Relief of profound feedback inhibition of mitogenic signaling by RAF inhibitors attenuates their activity in BRAFV600E melanomas. Cancer Cell 22: 668-682.

132. Cheung M, Sharma A, Madhunapantula SV, Robertson GP (2008) Akt3 and mutant V600E B-Raf cooperate to promote early melanoma development. Cancer Res 68: 3429-3439.

133. Tran MA, Gowda R, Sharma A, Park EJ, Adair J, et al. (2008) Targeting V600EB-Raf and Akt3 using nanoliposomal-small interfering RNA inhibits cutaneous melanocytic lesion development. Cancer Res: 7638-7649

134. Bedogni B, O'Neill MS, Welford SM, Bouley DM, Giaccia AJ, et al.(2004) Topical treatment with inhibitors of the phosphatidylinositol 3'kinase/Akt and Raf /mitogen-activated protein kinase kinase/ extracellular signal-regulated kinase pathways reduces melanoma development in severe combined immunodeficient mice. Cancer Res: 2552-2560

135. Bedogni B, Welford SM, Kwan AC, Ranger-Moore J, Saboda K, et al. (2006) Inhibition of phosphatidylinositol-3-kinase and mitogen-activated protein kinase kinase $1 / 2$ prevents melanoma development and promotes melanoma regression in the transgenic TPRase mouse model. Mol Cancer Ther: 3071-3077

136. Shimizu T, Tolcher AW, Papadopoulos KP, Beeram M, Rasco DW, et al. (2012) The clinical effect of the dual-targeting strategy involving $\mathrm{PI} 3 \mathrm{~K} / \mathrm{AKT} / \mathrm{mTOR}$ and RAS/MEK/ERK pathways in patients with advanced cancer. Clin Cancer Res 18: 2316-2325.

137. Molhoek KR, Brautigan DL, Slingluff CL Jr (2005) Synergistic inhibition of human melanoma proliferation by combination treatment with B-Raf inhibitor BAY43-9006 and mTOR inhibitor Rapamycin. J Transl Med 3: 39.

138. Lasithiotakis KG, Sinnberg TW, Schittek B, Flaherty KT, Kulms D, et al. (2008) Combined inhibition of MAPK and mTOR signaling inhibits growth, induces cell death, and abrogates invasive growth of melanoma cells. J Invest Dermatol: 2013-2023 